\title{
The Implication of School Based Management Towards Head Master Performance in District Level
}

\author{
Deti Rostini ${ }^{1}$, Ricky Yoseptry ${ }^{2}$, Lili Dianah $^{3}$ \\ \{ yankty59@gmail.com ${ }^{1}$, rickyyoseptry01@gmail.com ${ }^{2}$, lilihdianah@gmail.com ${ }^{3}$ \}
}

Universitas Islam Nusantara, Bandung, Indonesia ${ }^{1,2,3}$

\begin{abstract}
School-Based Management is a management model that gives autonomy to schools and encourages participatory decision-making that involves all school members. The school autonomy requires monitoring toward the principal performance in the ability to perform in school leadership. This study was conducted to assess the principal performance in managerial and supervisory capability. Research carried toward 66 principals in one of the districts in West Java. technology to improve school / madrasah teaching and management. In supervision, the highest ability o the principal was in planning academic supervision programs in order to increase teacher professionalism, and the lowest ability was to follow up on the results of academic supervision in order to improve teacher professionalism.
\end{abstract}

Keywords: Performance, The Principal, School-Based Management.

\section{Introduction}

The principalism of school principals in managing schools is a key element in producing quality schools. To achieve the educational objectives, there is a need for cooperation between fellow school personnel (teachers, students, principals, administrative staff) and those outside the school that are related to the school. Cooperation in the organization of this school should be maximally (Suryosubroto, 2004: 16). School management or school management means managing the substances of education in order to run in an orderly, smoh, and completely integrated in a system of cooperation to achieve goals effectively and efficiently (Mulyasa, 2009).

MoNE establishes school management with School Based Management (SBM) concept. SBM is one of the compulsory strategies set as a standard in developing school management excellence. This assertion is set forth in Law. 20 of 2003 on National Education System in article 51, paragraph 1 , that the management of the secondary education unit is implemented based on the minimum service standard with the principle of school based management. MBS is a management model that gives greater autonomy to schools, encourages participatory decision-making that directly involves all citizens of schools, employees, parents, and communities to improve school quality based on national education policy (MoNE 2007: 12).

\subsection{School Based Management (MBS)}

MBS is one manifestation of educational reform, which offers schools to provide better and adequate education for learners. Autonomy in management is a potential for schools to 
improve staff performance, offer direct participation of relevant groups, and increase public understanding of education (Mulyasa, 2009). MBS is a model of school management by granting greater authority at the school level to manage their own schools directly. This great authority has several advantages such as: (a) school policies and authorities have a direct influence on students, parents, and teachers; (b) aims to utilize the resources and utilization of internal school resources; (c) effective in conducting student coaching such as attendance, learning outcomes, teacher morale and school climate; and (d) mutual concern for decision making, empowering teachers, school management, school redesign and planning changes (Nurkholis, 2003: 11).

SBM includes an inclusive of effective school elements, which are categorized into inputs, processes, and outputs. Educational input consists of resources and software and expectations as a guide for the ongoing process of education. Processes in education are the processes of decision-making, institutional management, program management, teaching-learning, monitoring and evaluation by emphasizing that the teaching-learning process has the highest level of importance compared to other processes. School output is a school achievement resulting from learning and management processes in schools. This output is in the form of academic achievement and non academic achievement (Depdiknas, 2007: 16).

To know the extent of managerial and supervisory implementation of the principal in the implementation of SBM, it is necessary to evaluate the performance of the principal. Performance appraisal is a formal system for reviewing and evaluating the performance of individuals or teams in performing their duties (Mondy, 2008). Or the process the organization does to evaluate the work of its employees (Liao et al., 2010). Performance appraisals involve performance evaluations based on judgments and opinions of subordinates, co-workers, superiors, other managers, and even employees themselves (Schuler \& Jackson, 2006).

\subsection{Principal Performance}

Assessing the performance of the principal is important and challenging. This is necessary because the principal's performance assessment at the district level can measure and ensure accountability of principals in leading, managing and supervising schools so as to create schools that meet established quality standards. Assessment of the principal is important for improved principal accountability, good leadership execution, and provision of information resources or data that can be used for professional development as needed. The Foundation (2009) suggests that well-designed and well-designed school principals can be a powerful and constructive way to identify the strengths and weaknesses of school principals and encourage focus on action in improving better teaching and learning.

To know the extent of managerial and supervisory implementation of the principal in the implementation of SBM, it is necessary to evaluate the performance of the principal. Performance appraisal is a formal system for reviewing and evaluating the performance of individuals or teams in performing their duties (Mondy, 2008). Or the process the organization does to evaluate the work of its employees (Werther \& Davis, 1996). Performance appraisals involve performance evaluations based on judgments and opinions from subordinates, coworkers, superiors, other managers, and even employees themselves (Schuler \& Jackson, 2006).

Some comprehensive assessments are conducted using feedback approaches through interviews or surveys with teachers, parents, or students. Assessment should be able to identify and determine the association or relationship between leadership behaviors and teacher enhancement and student outcomes. The findings obtained can provide information related to the development and training to become a professional school principal. 
Performance appraisals are performed by appraisers by collecting information on appraised formal performance appraisals to assess priceless performance by comparing them with performance standards periodically to assist HR management decision making (Wirawan, 2009).

Performance appraisal by Werther and Davis (1996: 342) has several objectives and benefits for the assessed organization and staff: (a) Performance Improvement, which allows employees and managers to take action related to performance improvement; (b) Compensation adjustment, which helps decision-makers to determine who is eligible to receive a raise or vice versa; (c) Placement decision, which determines promotion, transfer, and demotion; (d) Training and development needs, ie evaluating training and development needs for employees to optimize their performance; (e) Carrer planning and development, which guides to determine the type of career and career potential that can be achieved; (f) Staffing process deficiencies, which affects employee recruitment procedures; (g) Informational inaccuracies and job-design errors, which help explain what mistakes have been made in human resource management especially in the field of job-analysis information, jobdesign, and human resource management information systems; (h) Equal employment opportunity, which implies that the placement decision is non-discriminatory; (i) External challenges, that is to look at the influence of external factors from family, personal finance, health, and others; (j) Feedback, which provides feedback on personnel matters as well as to the employee itself.

\section{Method}

This study uses descriptive analytical methods that are quantitative. The research technique is done by interview and observation. Sample determination technique in this research use saturated sampling that is all member of population used as sample (Sugiyono, 2009:68). The research instrument is a list of performance appraisals conducted by an assessor from one district in West Java. The assessed principals are 66 principals of junior high schools in one district in West Java.

\section{Result and Discussions}

School Based Management is a strategy to create an effective and productive school. $\mathrm{SBM}$ is one form of educational reform that gives autonomy to the school to organize life according to its potential, demands and needs. Autonomy in management is the potential for schools to improve the performance of the educational staff, offering direct participation of related groups, and enhance people's understanding of education.

In the new paradigm of education management, schools have the authority to plan according to their needs (school-based plan). To improve the quality, schools must perform needs analysis, then develop quality improvement plans based on the needs analysis. Schools also have the authority to conduct internal evaluations to monitor the implementation process and the programs that have been implemented. The evaluation is usually called self-evaluation which must be done honestly, fairly and transparently in order to reveal the real information.

Implementation of MBS will be strongly influenced by several factors, both internal and external. In this research the implementation of MBS is influenced by the performance of 
principals, including school management and supervision. MBS will be successful if supported by the principal's professional skills in managing the school effectively and efficiently.

In planning the school for various levels of planning, as much as 97\% (64 votes) principals are considered to meet the expected performance, namely: (a) be able to compile documentation RKJM, CTR / RKAS agreed stakeholders, destination activities measurable, meet priorities, clear budget allocations, covering 8 (eight) SNPs and making program or EDS evaluation instruments; (b) able to formulate the vision of the school mission which is the result of a joint decision, serves as a determinant of the direction of development of a socialized school program; (C) ability to determine strategies for achieving each goal on compliance activities outlined in the indicators of achievement that are specific, measurable, realistic and timeless; (d) be able to complete the program with an evaluation plan, complemented by an instrument that measures the program's implementation and achievement. While 3\% ( 2 people) considered less able to arrange the plan as expected. These results indicate that the principal of SMP Negeri in school planning ability has fulfilled the expected performance. Coaching is done on 2 (two) principals for school achievement can be improved.

Meanwhile, in preparing school planning for various levels of planning, as many as 97\% (64 people) principals are considered to meet the expected performance, namely: (a) able to prepare RKJM documentation, RKT / RKAS agreed by stakeholders, measurable activity objectives, priority, clear budget allocation, covering 8 (eight) SNPs and making program evaluation instruments or EDS; (b) able to formulate the vision of the school mission which is the result of a joint decision, serves as a determinant of the direction of development of a socialized school program; (C) ability to determine strategies for achieving each goal on compliance activities outlined in the indicators of achievement that are specific, measurable, realistic and timeless; (d) be able to complete the program with an evaluation plan, complemented by an instrument that measures the program's implementation and achievement. While 3\% ( 2 people) considered less able to arrange the plan as expected. These results indicate that the principal of SMP Negeri in school planning ability has fulfilled the expected performance. Coaching is done on 2 principals so that school achievement can be improved.

This result demonstrates the need for guidance on 11 principals, as successful change management and school development depend heavily on teamwork. Teamwork is a characteristic demanded by School Based Management, since the educational output is the collective outcome of the school's residents rather than individual outcomes. Therefore, the culture of cooperation among the functions within the school, should be a habit of everyday life of the citizens of the school.

The ability of school principals to create a conducive and innovative school environment and climate for the learning of learners, as many as $88 \%$ (58 people) principals are considered to meet the expected performance criteria of the principal, which are (a) able to become competitive examples of quality in encouraging improvement of academic and non academic achievement of learners; (b) able to equip facilities and infrastructure to create conducive and innovative learning atmosphere for learners, the principal is able to create a beautiful, clean, shady, school environment that encourages learners, collaborates, develops school environment as media exhibition of creative works of learners; (c) able to facilitate activities to improve reading culture and writing culture of learners, schools should have library visit data, student lending, book renewal and reading materials, the availability of ICTbased learning resources, and publications of written materials; developing a writing 
competition of school-level learners; (d) able to facilitate academic and non academic competitions for learners, the school must have documents of competition activities starting from the school level, the acquisition of award certificates, trophies, academic and non academic competition trophies. Whereas and 12\% (8 people) are considered less able to create a conducive and innovative school culture and climate for the learning of learners.

It is necessary to coach the 8 principals in the ability to create school culture and climate, because the implementation of school-based management needs to be supported by a conducive school climate for the creation of a safe, comfortable and orderly environment so that the learning process can take place calmly and pleasantly. Such a climate will encourage the creation of an effective learning process, which emphasizes learning to know, learning to do, learning to be, and learning to live together harmoniously (learning to live together). Effective learning will stimulate the growth of independence and decrease dependence among the citizens of the school, be adaptive and proactive and have a high entrepreneurial spirit (tenacious, innovative, and risk-taking). For these purposes, schools need to be equipped by educational facilities and infrastructure, as well as adequate learning resources.

The ability of school principals to manage teachers and staff optimally, as many as $76 \%$ (53 people) principals are considered to meet the expected performance criteria of principals, namely (a) able to develop educator planning and educational staff, the principal must have a teacher- on an ongoing basis based on the results of performance evaluation as well as the results of monitoring of implementation and achievement data of coaching program involving the school development team and agreed by all educators and education personnel in the school; (b) able to carry out periodic guidance to improve the quality of school human resources, the principal should have a document on the implementation of teacher development activities by the principal, for example: minutes of the meeting, delivery of materials in the implementation of the training, and records of regular coaching activities, special coaching notes individually or group or enhancement of teamwork such as outbound training; (c) able to facilitate teachers and administrative staff to enhance competence development activities, principals should have data of principal's support in facilitating administrative staff to improve professional quality such as letters of duty to follow sustainable profession improvement activities, action research, innovation work, and allocate activity budgets ; (d) able to monitor and assess the application of training outcomes in school work, the principal must have a training program evaluation document or the development of the educator profession and education personnel describing the objectives, data on the evaluation of the achievement of objectives and the presence of follow up advice realized. While 24\% (13 people) principals are considered less than optimal in managing teachers and staff.

The guidance was carried out on 13 principals in managing teachers and staff, as the education staff, especially teachers, was one of the strategic factors of a school. Therefore, the management of education personnel, from the needs analysis, planning, development, job evaluation, employment relationship, to the rewards, is an important claim for the principal. The development of education personnel should be done continuously, given the rapid development of science and technology.

In managing the acceptance of new learners, the placement and capacity development of learners, as many as $98 \%$ (65 people) principals are considered capable of meeting the expected performance in terms of: (a) able to prepare the planning acceptance, management and development competence of learners, have a document of new student acceptance program, student acceptance criterion, data of analysis result of learning of initial learner, academic discipline, and strategy documented in development of targeted and measurable 
student competence in the last 2 years; (b) have a program of self-potential development and achievement of learners. Strategies that schools use creatively can enhance the collaboration of educators and education personnel, competence development and achievement of educators and tenders, development of competitiveness and achievement of learners in academic and non academic fields; (c) able to facilitate activities to improve habituation through the cultivation of values. Strategies that principals use in developing homeland love, national insights, global insights, responses to national strategic issues or global strategic issues integrated into academic and non-academic activities in the form of programming, implementation and monitoring of implementation, and results achieved; (d) able to facilitate self-development activities for learners, educators and education personnel. The principal must have program targets, realization data of the implementation of self-development program of learners, educators and other education personnel data achievement program, and the existence of measurement data of the implementation and achievement. While $2 \%$ (1 person) is considered less capable in managing the acceptance of new learners, placement and capacity building of learners.

To implement school-based management effectively and efficiently, the principal needs to raise awareness, enthusiasm, learning discipline, exemplary and human relationships as a capital for the realization of a conducive working climate. Furthermore, the principal is required to perform his function as a managerial school in improving the learning process, by supervising the class, fostering and giving positive suggestions to the teacher. The principal must also exchange ideas, brainstorming suggestions, and comparative studies between schools to absorb leadership tips from other schools. From the results of the study, all principals of $100 \%$ (66 people) are considered capable of managing curriculum development and learning activities in accordance with the direction and objectives of national education.

This suggests that all school principals: (a) have been able to effectively guide the application of the principles of KTSP development in IHT activities, workshops, coordination meetings and MGMP / KKG activities; (b) able to control the implementation of the SBC based on the educational calendar, issue a decree on the division of teaching tasks, and apply academic rules; (c) able to facilitate the effectiveness of teacher work teams in order to improve the quality of learning; (d) able to develop innovative learning services through the development of renewable learning tools and resources; (e) able to facilitate learners in developing collaboration and academic and non academic competition.

Ability to manage school resources according to effective, efficient and accountable management principles, 94\% (62) of principals are considered to meet the expected performance criteria of principals: (a) able to direct the administration of records and archives effectively; (b) able to direct the administration of infrastructure facilities effectively; (c) able to direct the administration of personnel administration in accordance with the development of personnel development; (d) able to direct the management of financial administration in an effective, efficient, transparent and accountable manner; (e) capable of effectively directing the administration of learners; (f) able to direct the administration of the library administration effectively; ( $\mathrm{g}$ ) able to direct the management of laboratory administration. While $6 \%$ (4 people). Head of school dinggan not yet able to manage school resources according to effective management principle, efficient and accountable.

The need for guidance on these four principals, because the principal as an administrator has a very close relationship with various administrative management activities that are recording, preparation and documentation of all school programs. Specifically the principal must have the ability to manage the curriculum, manage the administration of facilities and infrastructure, manage the administration of archives and manage the financial 
administration. These activities need to be done effectively and efficiently in order to support school productivity. For that the principal must be able to describe the above skills in operational tasks.

The ability to utilize information technology advancement for the improvement of learning and school management, as many as $71 \%$ (47 persons) principals are considered to meet the expected performance criteria of principals, namely: (a) able to develop effective administrative management system with the support of the application of information and communication technology, there is the application of ICT in the management of administration-administration letter, infrastructure, staffing, kepeserta education and finance; (b) capable of effectively managing instructional administration with support for the application of information and communication technology; (c) able to develop a library management system effectively with the support of the application of information and communication technology. While 29\% (19 people) principals are considered less able to take advantage of advances in information technology for the improvement of learning and school management.

It is necessary to coach the 19 principals because in the era of globalization we are in an open society and full of competition. This means that society is in the best possible condition. The era of globalization is the era of communication, the era of technology is very fast and sophisticated. Therefore, both learners and educators must be digital literate.

The main activities of education in schools in order to realize the goal is learning activities, so that all activities of the school organization lead to the achievement of efficiency and effectiveness of learning. Therefore one of the tasks of the principal is as a supervisor that supervises the work done by educational personnel. Supervision is a specially designed process to assist teachers and supervisors in learning the day-to-day tasks at school, in order to use their knowledge and ability to provide better service to parents of learners and schools, and to make the school a learning community which is more effective (Mulyasa, 2009).

The ability of academic supervision is important because supervision is a process specially designed to assist teachers in learning the day-to-day tasks at school, in order to use their knowledge and ability to provide better service to parents of learners and schools, and to school as a more effective learning society.

In the ability to carry out academic supervision of teachers using appropriate approaches and supervision techniques, as many as 58\% (38 persons) of principals are considered to meet the expected performance criteria of principals, namely: (a) able to hold initial meetings to capture data plan lesson and set the focus of supervision activities; (b) capable of carrying out monitoring activities of the lesson and making objective and selective notes as material for problem-solving supervision; (c) able to conduct reflection meetings, analyze observation records, and summarize observations; (d) able to together with the teacher to prepare recommendations for improvement follow-up in the form of item analysis, remedial and enrichment activities. While $42 \%$ (28 people) principals are considered less able to carry out academic supervision of teachers by using appropriate approaches and supervision techniques.

The guidance of 28 principals is important, because the supervision and control of principals on teachers, especially teachers, aims to improve the professional skills of teachers and improve the quality of learning through effective learning. Regular learning evaluation is not only shown to determine the level of absorption and ability of learners, but the most important is how to utilize the evaluation results to improve and improve the learning process in school. Therefore the evaluation function becomes very important in order to improve the quality of students and the quality of school as a whole and continuously. 
For the ability to follow up the results of academic supervision in order to increase the professionalism of teachers, as many as $53 \%$ (35 people) principals are considered capable of meeting the expected performance criteria of principals, namely: (a) able to facilitate teachers in planning follow-up improvements in learning outcomes assessment system; (b) able to check the implementation of the recommendations by the teacher; (c) able to carry out guidance and teacher development as a follow up of supervision activities; (d) able to use supervised data for mapping the achievement of the program as a basis for subsequent cycle improvement. While $47 \%$ (31 people) principals are considered less able to follow up the results of academic supervision in order to increase the professionalism of teachers. The coaching of the 31 principals is very important, because the achievement of excellent quality schooling requires the ability of professional teachers. Increased professionalism of teachers will affect the learning process and learning outcomes of learners.

\section{Conclusion}

The principal's performance in managerial skills and principal supervision is central to improving excellent school quality, teacher professionalism, and excellent learner quality. The results of research on the principal of SMP Negeri in one district in West Java, showed the highest managerial ability in managing curriculum development and learning activities in accordance with the direction and objectives of national education, as well as the lowest managerial skills in Utilizing the advancement of information technology for the improvement of learning and management as / madrasah. While in the supervision ability, the highest ability of headmaster in planning academic supervision program in order to increase the professionalism of teachers, and the lowest ability in following up the results of academic supervision in order to increase the professionalism of teachers.

From the results of this study to the principal, it is necessary to supervise and continuous supervision of some principals who have managerial and supervision skills that are considered not meet the expected school performance criteria.

\section{References}

[1] Depdiknas. (2007). Manajemen Berbasis Sekolah. Jakarta: Direktorat Jenderal Manajemen Pendidikan Dasar dan Menengah.

[2] Foundation, W. (2009). Assessing the effectiveness of school leaders: New directions and new processes. New York: Author.

[3] Liao, H., Martocchio, J. J., Joshi, A. (2010). Research in Personnel and Human Resources Management, Vol. 29. United Kingdom: Emerald Group Publishing Limited.

[4] Mondy, R.W. (2008). Manajemen Sumber Daya Manusia, Edisi Kesepuluh (terjemahan). Jakarta: Penerbit Erlangga.

[5] Mulyasa, E. (2009). Menjadi Kepala Sekolah Profesional. Bandung: PT Remaja Rosdakarya.

[6] Nurkholis. 2005. Manajemen Berbasis Sekolah: Teori, Model dan Aplikasi. Grasindo: Jakarta. PT Gramedia Widiasarana Indonesia.

[7] Schermerhorn, J.R. (1996). Management, 5th Ed. New York: John Wiley \& Sons, Inc.

[8] Schuler, R. S. \& Jackson, S. E. (2006). Human Resource Management, International Perspective. Mason: Thomson South-Western.

[9] Suryosubroto, B. (2004). Manajemen Pendidikan di Sekolah. Jakarta: Rineka Cipta. 
[10] Sugiyono. (2009). Metode Penelitian Bisnis: Pendekatan Kuantitatif, Kualitatif, dan $R$ \&D. Bandung: Alfabeta.

[11] Wirawan. (2009). Evaluasi Kinerja Sumber Daya Manusia: Teori, Aplikasi, dan Penelitian. Jakarta : Penerbit Salemba Empat. 